\title{
KOETTU TYÖKYKY JA HYVINVOINTITEKIJÄT LAPIN 40-59-VUOTIAASSA VÄESTÖSSÄ
}

\section{Johdanto}

Väestön terveyden ja työkyvyn ylläpitäminen ja edistäminen ovat tärkeitä yhteiskunnallisia tavoitteita. Sosiaali- ja terveyspolitiikan strategiassa Sosiaalisesti kestävä Suomi 2020 todetaan pyrkimyksenä olevan vähentää hyvinvointi- ja terveyseroja sekä pidentää työuria, alentaa työttömyyttä ja vähentää työkyvyttömyyttä. Väestön hyvinvointi- ja työkykyeroja selittää osaltaan rakenteellinen ja kulttuurinen eriarvoisuus, joka tuottaa epätasa-arvoa elinoloihin ja elintapoihin (Rahkonen ym. 2011). Yhteiskunnallisen muutoksen myötä työkyvyn käsite on laajentunut moniulotteiseksi. Työkyky määrittyy yksilön ominaisuuksien, työn ja työorganisaation sekä yhteiskunnallisen ja kulttuurisen ympäristön vuorovaikutuksessa (Ilmarinen ym. 2006, Lederer ym. 2014, Gould ym. 2015). Kansalaisten työkyvyn ylläpito edellyttää hyvinvoinnin ja työssä jaksamisen edistämistä yksilöllisin ja rakenteellisin toimin sekä kuntoutuksen mahdollisuuksien hyödyntämistä.

Työkyvyttömyyden alkavuus lisääntyy iän myötä, ja 40 vuotta täyttäneillä työkyvyttömyyden riski kasvaa vuosi vuodelta. Vuonna 2014 työkyvyttömyyseläkkeelle siirtyneistä 26 prosenttia oli 45-54-vuotiaita ja 54 prosenttia 55-62-vuotiaita; lukuihin sisältyvät sekä pysyvät työkyvyttömyyseläkkeet että kuntoutustuet. Eläkkeiden alkavuus on työntekijäammateissa selvästi suurempaa kuin asiantuntija-ammateissa (Rahkonen ym. 2011); yli 40-vuotiaiden ikäryhmissä työntekijöiden ja asiantuntijoiden välinen ero eläkkeiden alkavuudessa lisääntyy joka ikävuosi (Pensola ym. 2010).

Työkyvyttömyyseläkkeiden sairausperusteissa korostuvat mielenterveyden ja käyttäytymisen häiriöt ja tuki- ja liikuntaelinten sairaudet (esim. Nyman \&t Kiviniemi 2015). Masennus on mielenterveyden häiriöiden perusteella alkavissa eläkkeissä yleisin eläkkeen syynä oleva sairaus. Eläkkeelle johtavat nuorten aikuisten mielenterveysongelmat ovat viime aikoina saaneet huomiota (esim. Ahola ym. 2014), mutta suurinta myös mielenterveyden häiriöihin perustuvien eläkkeiden alkavuus on yli 50-vuotiailla (Pensola ym. 2010).

Työkykyä voidaan tarkastella paitsi sairauspoissaolojen ja työkyvyttömyyseläkkeiden heijastamana lyhyt- tai pitempiaikaisena työkyvyttömyytenä, myös asiantuntija-arvioon tai ihmisen kokemukseen perustuvana ilmiönä. Koettu työkyky perustuu ihmisen käsitykseen omista voimavaroistaan, potentiaalisen työn tai työyhteisön hänelle asettamista vaatimuksista ja odotuksista sekä työmarkkinoiden hänelle antamista mahdollisuuksista. Se on sidoksissa ihmisen ja yhteiskunnan väliseen suhteeseen, käytössä oleviin resursseihin ja siihen, miten ihminen hahmottaa mahdollisuuksiaan sosiaalisissa rakenteissa. Tutkimuksissa koettua työkykyä on selvitetty muun muassa vastaajan kolmiportaisella arviolla työkyvystään (täysin työkykyinen/osittain työkyvytön/täysin työkyvytön), asteikol- 
le 0-10 sijoittuvalla työkykypistemäärällä sekä Työterveyslaitoksen työkykyindeksillä ja sen muunnoksilla (esim. Gould ym. 2015, McGonagle ym. 2015).

Myös koetussa työkyvyssä on selvät ikäryhmittäiset ja sosiaaliluokkaerot. Erityisen ongelmallisia ryhmiä ovat vähän koulutetut, työttömät, yksinäiset miehet ja vanhimmat työssä käyvät naiset (Gould ym. 2006a). Näissä ryhmissä korostuvat työelämän ongelmien rinnalla erilaiset hyvinvointiuhat ja sosiaalisten suhteiden ongelmat, mikä liittää työkyvyn edistämisen myös yleisen syrjäytymisen uhkan torjumiseen.

Ihmisen kokemus tilanteestaan on merkittävä tekijä työhön sitoutumisen ja työkyvyttömyyseläkkeelle hakeutumisen kannalta. Koettu työkyky ennustaa varsin hyvin tulevaa työkyvyttömyyttä tai työmarkkina-asemassa tapahtuvia muutoksia (Tuomi ym. 1997b, Alavinia ym. 2009, Ahlstrom ym. 2010). Bethgen ym:iden (2012) mukaan se ennusti työttömyyden ja pitkittyneen sairausloman ohella myös koettua kuntoutustarvetta, aikomusta hakeutua kuntoutukseen ja kuntoutuspalvelujen käyttöä. On toisaalta syytä huomata, että myös työkyvyttömyyseläkkeellä ja osatyökyvyttömyyseläkkeellä olevista osa kokee työkykynsä riittäväksi ainakin osa-aikaiseen tai tilapäiseen työhön (Gould \& Kaliva 2010). Koetun työkyvyn ja siihen yhteydessä olevien resurssien ja hyvinvointivajeiden tutkiminen on tärkeää pyrittäessä parantamaan työkyvyn ylläpidon ja varhaisen kuntoutuksen keinoja, vahvistamaan ihmisen työmarkkina-asemaa, poistamaan työmarkkinoille palaamisen esteitä sekä ylläpitämään hyvinvointia myös työelämän ulkopuolella.

Elämänhallinta viittaa ihmisen kokemukseen, että hän voi toimillaan vaikuttaa elämäänsä ja hänellä on käytössään resursseja, joita hän voi toiminnassaan hyödyntää. Vahva hallinnan tunne tukee ihmisen selviytymistä kuormittavissa tilanteissa ja ehkäisee psyykkisten ongelmien muodostumista elämänkulun aikana (Pearlin ym. 2007). Yksittäisissä tutkimuksissa hallinnan tunne on ennakoinut ammatillisen kuntoutusohjelman myönteistä tulosta (Millet \&t Sandberg 2003), selkäkuntou- tuksen jälkeistä työssä jatkamista (Härkäpää 1992) ja työssä käyntiä useita vuosia ammatillisen kuntoutuksen jälkeen (Gould ym. 2012a). Amerikkalaisessa aineistossa hallinnan tunne oli myös yhteydessä koettuun työkykyyn (McGonagle ym. 2015).

Myös sosiaalinen tuki ja luottamus ovat resursseja, jotka ovat erilaisten vaikutusmekanismien kautta yhteydessä ihmisen hyvinvointiin (esim. Thoits 2011, Giordano \& Lindström 2016). Terveys 2000 -tutkimuksen koko väestöä koskevassa aineistossa sosiaalisella tuella oli yhteys koettuun työkykyyn (Pensola \&t Järvikoski 2006a). Työssä käyvässä väestössä sosiaalisen tuen yhteys työkykyyn ja eläkkeelle siirtymiseen on tuottanut osin ristiriitaisia tuloksia (esim. Pasternack ym. 2015). Sosiaalisella verkostolla voi olla vammaisuuteen, ikääntymiseen tai pitkäaikaistyöttömyyteen liittyvien kielteisten asenteiden ja stigman takia myös kielteisiä vaikutuksia työkykykokemukseen. Esimerkiksi Solem (2008) pohtii asenneilmapiirin vaikutuksia koetun työkyvyn heikentymiseen iän myötä, ja Rinaldi ym. (2008) kuvaavat stereotypioiden vaikutuksia noidankehänä, jonka tuloksena mielenterveysongelmia kokeva henkilö ei luota työkykyynsä ja luopuu yrittämästä työllistyä.

Työkyvyttömyyden riski kasvaa Suomessa pohjoista ja itää kohti. Lapissa ja Kainuussa työkyvyttömyyseläkkeelle siirtyminen on lähes kaksinkertaista pienimmän työkyvyttömyyseläkealkavuuden maakuntiin verrattuna. Samansuuntaisia eroja on koetussa työkyvyssä: Etelä-Suomi eroaa maan muista alueista paremman työkyvyn mielessä, ja Itä- ja Pohjois-Suomen ei-kaupunkimaisissa kunnissa asuvat miehet kokivat itsensä täysin tai osittain työkyvyttömiksi yleisemmin kuin muilla alueilla asuvat miehet (Martelin ym. 2006). Alue-eroja on selitetty muun muassa terveydentilan vaihtelulla, eroilla elintavoissa ja sosiaalisessa pääomassa, työelämän ulkopuolella olevien osuudella, alueiden erilaisella koulutus-, elinkeino- ja ammattirakenteella sekä muuttoliikkeellä (Laaksonen \&t Gould 2013). Monipuolinen elinkeinorakenne ja hyvä työllisyystilanne voivat helpottaa työkyvyltään rajoittuneiden ja osatyökykyis- 
ten mahdollisuuksia jatkaa työssä.

Tässä tutkimuksessa selvitetään koettua työkykyä ja siihen liittyviä tekijöitä Lapissa, jossa aihetta ei tiettävästi ole aikaisemmin tutkittu. Lappi poikkeaa muusta Suomesta erityisesti pitkien etäisyyksien ja harvan asutuksen vuoksi, mikä voi osalla väestöä lisätä syrjäytymisriskiä. Lapin hyvinvointibarometrissa kiinnitetään huomiota viimeaikaiseen eriytymis- ja polarisoitumiskehitykseen. Teknologisen kehityksen, matkailun ja kaivostoiminnan tuottamat myönteiset vaikutukset koskevat osaa kuntia, kun taas muille asettavat haasteita muun muassa aleneva väestökehitys, erityisesti miesten työvoimaosuuden aleneminen ja hyvinvointipalvelujen saavutettavuus. (Suikkanen ym. 2014, Viinamäki 2014.)

Tämän artikkelin tavoitteena on selvittää, 1) onko koetussa työkyvyssä sekä sosiaalisia resursseja ja psyykkistä hyvinvointia kuvaavissa tekijöissä eroja sukupuolen ja pääasiallisen toiminnan mukaan 40-59-vuotiailla Lapissa asuvilla henkilöillä, ja

2) mitkä sosiaalisiin resursseihin ja psyykkiseen hyvinvointiin liittyvät tekijät ovat yhteydessä heikentyneeseen työkykyyn.

\section{Menetelmä}

Terveyden ja hyvinvoinnin laitos toteutti yhdessä Lapin sairaanhoitopiirin ja kahdentoista Mielen tuki -hankkeeseen kuuluvan jäsenkunnan kanssa vuonna 2012 kyselytutkimuksen, jolla koottiin tietoa väestön mielenterveydestä ja psyykkisestä hyvinvoinnista sekä asennoitumisesta mielenterveyden häiriöihin. Hanke oli osa kansallisen mielenterveys- ja päihdesuunnitelman toimeenpanoa. Väestörekisterikeskuksen väestötietojärjestelmästä tilattiin ositettu otanta 15-80-vuotiaista henkilöistä kunnittain siten, että alle 5000 asukkaan kunnista (8 kuntaa) otoskoko oli 400, yli 5000 asukkaan kunnista (3 kuntaa) 1000 ja Rovaniemellä 2000 henkilöä. Kokonaisotos oli 8200 henkilöä.

Kyselystä tiedotettiin ennen kyselyä informaatiokirjeessä ja lomakkeen mukana toimitetussa tiedotteessa. Uusintakyselyä ei taloudellisista syistä toteutettu. Osa palautuneista lomakkeista suljettiin tutkimuksen ulkopuolelle puutteellisten vastausten vuoksi tai siksi, että vastaaja ei iän tai asuinpaikkakunnan vuoksi kuulunut tutkimuksen kohderyhmään. Vastausprosentti oli 33; se oli miehillä matalampi kuin naisilla ja Tunturi-Lapissa matalampi kuin muilla alueilla. Ikäryhmistä nuorimmat ja kaikkein vanhimmat vastasivat keskiryhmiä heikommin. Vastaamisaktiivisuuden vaihtelua korjattiin painokertoimilla, jotka laskettiin iän, sukupuolen ja asuinalueen mukaisen kadon perusteella. Ikäryhmässä 40-59-vuotiaat oli vastanneita 959 (vastausprosentti 32), joista miehiä oli 481. Työssä tai koulutuksessa oli vastanneista $76 \%$, työttömänä $9 \%$, eläkkeellä $12 \%$ ja muussa tilanteessa $3 \%$.

\section{Muuttujat}

Koettua työkykyä selvitettiin työkykypistemäärällä, jossa vastaaja arvioi nykyistä työkykyään asteikolla 0-10, jossa 0 tarkoittaa työkyvyttömyyttä ja 10 elinikäistä parasta työkykyä. Työkykypistemäärän tulokset vastaavat työssä käyvässä väestössä melko hyvin Työterveyslaitoksessa kehitetyn työkykyindeksin (Tuomi ym. 1997a) tuloksia (Ahlstrom ym. 2010, Gould ym. 2015). Työkykypistemäärän perusteella työkyky voidaan luokitella huonoon (0-5), kohtalaiseen (6-7) ja hyvään (8-9) tai erinomaiseen (10) työkykyyn (esim. Gould ym. 2006b, Ahlstrom ym. 2010). Tässä tutkimuksessa selvitetään, miten työkykynsä heikentyneeksi kokeneet (0-7 p.) eroavat työkykynsä edelleen hyväksi tai erinomaiseksi (8-10 p.) arvioineista.

Taustamuuttujia olivat sukupuolen, siviilisäädyn ja seutukunnan (Rovaniemi, Itä-Lappi, Tunturi-Lappi, Pohjois-Lappi) lisäksi koulutus ja pääasiallinen toiminta. Koulutuksen osalta tiedusteltiin korkeinta peruskoulutuksen jälkeen suoritettua koulutusta tai tutkintoa. Vastausten perusteella muodostettiin 3-luokkainen koulutusmuuttuja: 1 = matala (ei ammattikoulutusta tai ammatillinen kurssi), 2 = keskitasoinen (ammattikoulu tai ammatillinen opisto), 3 = korkea (ammattikorkeakoulu tai korkeakoulu). Pääasiallisen toiminnan 
mukaan vastaajat luokiteltiin neljään luokkaan: 1 = työllinen, 2 = työtön, 3 = eläkkeellä, 4 = muussa tilanteessa. Ensimmäiseen ryhmään kuuluivat palkkatyössä olevat, yrittäjät ja maatalousyrittäjät sekä osa-aikatyötä tekevät (myös heidän ollessaan samanaikaisesti osa-aika- tai osatyökyvyttömyyseläkkeellä) ja harvalukuiset ammatillisessa koulutuksessa olevat. Eläke tarkoittaa tässä ikäryhmässä pääasiassa pysyvää työkyvyttömyyseläkettä tai kuntoutustukea. Muussa tilanteessa olevien pieneen, heterogeeniseen ryhmään kuului kuntoutuksessa ja sairauspäivärahalla olevia, kotitöitä tekeviä sekä omaishoitajia.

Elämänhallinnan mittarina oli Sense of Mastery (Pearlin \& Schooler 1978), jonka seitsemään osioon vastataan 4-portaisella asteikolla (täysin samaa mieltä - täysin eri mieltä). Mittarin vaihteluväli on 4-28. Aikaisemman käytännön mukaisesti (Stephens ym. 2000, Forsman ym. 2009) elämänhallinta määriteltiin vahvaksi, jos summapistemäärä sai vähintään arvon 23.

Sosiaalista tukea selvitettiin Oslo 3 -mittarin (Brevik \& Dalgard 1996, Nyqvist ym. 2013) kolmella osiolla (sellaisten läheisten ihmisten määrä, joihin voi luottaa vakavissa henkilökohtaisissa vaikeuksissa; mahdollisuus saada tarvittaessa apua käytännön ongelmissa; ihmisten osoittama mielenkiinto siihen, mitä tekee). Summapistemäärän vaihteluväli on 3-4; alfa-kerroin oli tässä aineistossa 0,59. Aikaisemman käytännön mukaisesti (Forsman ym. 2009) sosiaalinen tuki määriteltiin vähintään kohtalaiseksi, jos summapistemäärä sai vähintään arvon 10.

Sosiaalista luottamusta eli kognitiivista sosiaalista pääomaa (vrt. Forsman ym. 2009) mitattiin kolmella väitteellä (naapurustoon kuulumisen tunne; naapurustoon kuuluvien ihmisten luotettavuus; käsitys ihmisten luotettavuudesta yleensä), joiden paikkansa pitävyyttä arvioitiin 4-portaisella asteikolla (pitää täysin paikkansa - ei lainkaan pidä paikkaansa). Summamuuttujan vaihteluväli on 0-9. Alfa-kerroin oli tässä aineistossa 0,72. Summamuuttuja luokiteltiin mediaanin perusteella heikkoa (enintään 6) tai vahvaa (vähintään 7 p.) luottamusta kuvaavaksi. Käsitystä mie- lenterveysongelmiin liittyvästä stigmasta työpaikalla selvitettiin väitteellä "Jos työnantaja saa tietää työntekijän mielenterveysongelmista, työsuhde vaarantuu", johon vastattiin asteikolla 1 = täysin eri mieltä,..., 4 = täysin samaa mieltä.

Psyykkisen roolitoiminnan rajoituksia selvitettiin RAND 36 -mittarin (Aalto ym. 1999) kolmella osiolla, joissa tiedustellaan tunneelämään liittyvien seikkojen tuottamia ongelmia työssä tai muissa päivittäisissä toiminnoissa (on vähentänyt työhön tai muuhun toimintaan käytettyä aikaa; on saanut aikaan vähemmän kuin olisi halunnut; ei ole suorittanut töitä tai muita toimintoja yhtä huolellisesti kuin tavallisesti). Psyykkisen roolitoiminnan rajoitusten kriteeriksi asetettiin vähintään kahteen osioon annettu kyllä-vastaus.

Psyykkistä rasittuneisuutta mitattiin 12 kysymyksen GHQ-mittarilla (Goldberg 1972). Summapistemäärän ollessa vähintään 4 vastauksen katsottiin ilmentävän psyykkistä rasittuneisuutta (Aalto ym. 2012). Masennusoireilua mitattiin CIDI-SF-haastattelun neljällä kysymyksellä. Masennuksen kriteerinä oli kyllä-vastaus vähintään toiseen kahdesta seulontakysymyksestä (viimeksi kuluneen vuoden aikana vähintään 2 viikkoa kestänyt ajanjakso, jolloin a) oli surullinen, alakuloinen tai masentunut tai jonka aikana b) menetti mielihyvän kokemuksen ja kiinnostuksen kaikkeen tekemiseen) sekä myönteinen vastaus kahteen jatkokysymykseen (mielenkiinnon tai mielihyvän menetys on kestänyt vähintään suurimman osan päivästä; tunne on ollut vallitseva miltei joka päivä) (ks. Kessler ym. 1998, Forsman ym. 2009). Päihdeongelmien esiintymistä selvitettiin CAGE-kyselyn neljällä kysymyksellä (oletko koskaan ajatellut, että sinun täytyisi vähentää juomistasi; ovatko ihmiset ärsyttäneet sinua kriittisillä huomautuksillaan juomisestasi; oletko koskaan tuntenut syyllisyyttä juomisesi takia; oletko koskaan ottanut krapularyyppyjä aamulla). Päihdeongelma on todennäköinen, jos kysymyksiin annetaan vähintään kaksi myönteistä vastausta (ks. Ewing 1968, Dhalla \&t Kopec 2007).

Terveydentilaa arvioitiin EQ-VAS-asteikolla, jossa valitaan terveydentilaa vastaus- 
Taulukko 1. Taustamuuttujat, työkyky ja terveydentila sukupuolen ja pääasiallisen toiminnan mukaan.

\begin{tabular}{|c|c|c|c|c|c|c|c|c|}
\hline & \multicolumn{2}{|l|}{ Sukupuoli } & \multicolumn{5}{|c|}{ Pääasiallinen toiminta ${ }^{3}$} & \multirow{2}{*}{$\begin{array}{l}\text { Kaikki } \\
n=959\end{array}$} \\
\hline & $\begin{array}{l}\text { Miehet } \\
n=481\end{array}$ & $\begin{array}{l}\text { Naiset } \\
n=478\end{array}$ & $\mathrm{p}^{1}$ & $\begin{array}{l}\text { Työssä } \\
n=727\end{array}$ & $\begin{array}{l}\text { Työtön } \\
n=85\end{array}$ & $\begin{array}{l}\text { Eläkk. } \\
n=113\end{array}$ & $p^{2}$ & \\
\hline Miehiä, \% & & & & 46.5 & 61.7 & 63.7 & $* * *$ & 50.1 \\
\hline $\begin{array}{l}\text { lkä } \\
\text { M (sd) }\end{array}$ & $51.4(5.2)$ & $50.9(5.5)$ & NS & $50.7(5.4)$ & $52.4(4.6)$ & $53.7(4.6)$ & $* * *$ & $51.2(5.4)$ \\
\hline $\begin{array}{l}\text { Siviilisääty, \% } \\
\text { avio- tai avoliitossa } \\
\text { eronnut tai leski } \\
\text { naimaton }\end{array}$ & $\begin{array}{l}65.6 \\
12.9 \\
21.5\end{array}$ & $\begin{array}{l}79.3 \\
13.3 \\
7.4\end{array}$ & $* * *$ & $\begin{array}{l}78.8 \\
12.1 \\
9.1\end{array}$ & $\begin{array}{l}50.0 \\
15.5 \\
34.5\end{array}$ & $\begin{array}{l}49.6 \\
16.8 \\
33.6\end{array}$ & $* * *$ & $\begin{array}{l}72.5 \\
13.1 \\
14.5\end{array}$ \\
\hline $\begin{array}{l}\text { Koulutus, \% } \\
\text { matala } \\
\text { keskitasoinen } \\
\text { korkea }\end{array}$ & $\begin{array}{l}27.8 \\
57.2 \\
15.0\end{array}$ & $\begin{array}{l}15.1 \\
63.2 \\
21.7\end{array}$ & $* * *$ & $\begin{array}{l}15.6 \\
63.3 \\
21.1\end{array}$ & $\begin{array}{l}43.6 \\
51.3 \\
5.1\end{array}$ & $\begin{array}{l}43.3 \\
47.1 \\
9.6\end{array}$ & $* * *$ & $\begin{array}{l}21.5 \\
60.2 \\
18.3\end{array}$ \\
\hline $\begin{array}{l}\text { Seutukunta, \% } \\
\text { Rovaniemi } \\
\text { Itä-Lappi } \\
\text { Tunturi-Lappi } \\
\text { Pohjois-Lappi }\end{array}$ & $\begin{array}{l}29.9 \\
16.6 \\
37.4 \\
16.0\end{array}$ & $\begin{array}{l}30.9 \\
16.5 \\
36.3 \\
16.3\end{array}$ & NS & $\begin{array}{l}30.5 \\
15.8 \\
37.0 \\
16.6\end{array}$ & $\begin{array}{l}30.6 \\
14.1 \\
37.6 \\
17.6 \\
\end{array}$ & $\begin{array}{l}32.7 \\
21.1 \\
37.2 \\
8.8\end{array}$ & NS & $\begin{array}{l}30.4 \\
16.6 \\
36.9 \\
16.1 \\
\end{array}$ \\
\hline $\begin{array}{l}\text { Työkykypistemäärä } \\
\text { M (sd) } \\
0-5 \text { p. } \\
\text { 6-7 p. } \\
\text { 8-10 p. }\end{array}$ & $\begin{array}{l}7.67(2.21) \\
12.7 \\
15.0 \\
72.3 \\
\end{array}$ & $\begin{array}{l}7.97(2.04) \\
10.9 \\
11.9 \\
77.2 \\
\end{array}$ & NS & $\begin{array}{l}8.38(1.42) \\
3.9 \\
12.4 \\
83.8 \\
\end{array}$ & $\begin{array}{l}7.16(1.96) \\
17.4 \\
20.9 \\
61.6 \\
\end{array}$ & $\begin{array}{l}5.26(3.08) \\
50.4 \\
14.2 \\
35.4\end{array}$ & $\begin{array}{l}* * * \\
* * *\end{array}$ & $\begin{array}{l}7.82(2.13) \\
11.8 \\
13.4 \\
74.8 \\
\end{array}$ \\
\hline $\begin{array}{l}\text { Terveydentila } \\
M(s d)\end{array}$ & $77.6(17.0)$ & $79.9(15.7)$ & $*$ & $81.5(13.8)$ & 76.5 (14.9) & $66.2(22.4)$ & $* * *$ & 78.8 (16.4) \\
\hline
\end{tabular}

$* p<.05 ; * * p<.01 ; * * * p<.001$

${ }^{1}$ Testeinä Khiin neliö (jakautumat) ja riippumattomien ryhmien t-testi (keskiarvot).

${ }^{2}$ Testeinä Khiin neliö (jakautumat), varianssianalyyseissa F-testi (ikä) tai Brown-Forsythe -testi varianssien erisuuruuden vuoksi (työkykypistemäärä, terveydentila).

${ }^{3}$ Muussa tilanteessa olevien heterogeeninen ryhmä $(n=34)$ ei ole mukana ryhmävertailussa.

hetkellä parhaiten kuvaava vaihtoehto asteikolta 0-100 (Brooks \& EuroQol Group 1996).

\section{Tilastolliset analyysit}

Aineisto analysoitiin SPSS Statistics -ohjelman versiolla 21. Sukupuolen ja pääasiallisen toiminnan mukaisia eroja selvitettiin ristiintaulukoilla (Khiin neliötesti) ja varianssianalyyseilla (F-testi ja erisuurten varianssien tilanteessa Brown-Forsythen testi) sekä korrelaatioanalyyseilla. Heikentyneeseen työkykyyn yhteydessä olevia tekijöitä analysoitiin logistisella regressioanalyysilla. Työkykypistemäärästä muodostettiin kaksiluokkainen muuttuja, jonka avulla työkykyään pis- temäärillä 0-7 kuvanneita verrattiin niihin, jotka antoivat työkyvylleen arvion 8-10. Selittävinä muuttujina käytettiin pääasiallista toimintaa neliluokkaisena ja kaksiluokkaisina sukupuolta, parisuhteessa elämistä (aviotai avoliitossa vs. naimaton, eronnut tai leski), peruskoulutuksen jälkeistä koulutusta (matala vs. keskitasoinen tai korkea), sosiaalista tukea (heikko vs. vähintään kohtalainen), sosiaalista luottamusta (heikko vs. vahva), hallinnan tunnetta (huono vs. hyvä), psyykkisen roolitoiminnan rajoituksia (enintään yksi vs. useampi kyllä-vastaus), psyykkistä rasittuneisuutta (ei vs. kyllä), todennäköistä masennusta (ei vs. kyllä), todennäköistä päihdeongelmaa (ei vs. kyllä) ja käsitystä työsuhteen vaarantumises- 
ta mielenterveysongelmien takia (eri mieltä vs. samaa mieltä). Terveydentilaa ja ikää käytettiin analyyseissa jatkuvina muuttujina.

Logistisissa regressioanalyyseissa selvitettiin ensin kunkin selittävän muuttujan yhteys yksittäin selitettävään muuttujaan käyttäen kovarianttina ikää (malli 0). Nämä analyysit tehtiin erikseen kaikilla vastanneilla, miehillä ja naisilla sekä työssä olevilla. Jatkoanalyysit tehtiin erikseen kaikilla vastanneilla ja työssä olleilla. Malli 1 sisälsi sosiodemografiset sekä sosiaalista tukea, luottamusta ja elämänhallintaa koskevat muuttujat. Malli 2 sisälsi edellisten lisäksi psyykkisen hyvinvoinnin ongelmia koskevat muuttujat ja malli 3 vielä terveydentilamuuttujan. Todennäköistä päihdeongelmaa ja käsitystä työsuhteen vaarantumisesta mielenterveysongelmien takia ei käytetty malleissa 1-3, koska mallien tapausmäärät haluttiin pitää mahdollisimman suurina.

Mallien soveltuvuus (goodness-of-fit) testattiin Hosmer-Lemeshowin menetelmällä. Yksittäisten muuttujien selitysosuuden merkitsevyyttä arvioitiin Waldin testillä. Eri malleja verrattaessa seurattiin myös pseudoselityskertoimien (Coxin ja Snellin $\mathrm{R}^{2}$ ja Nagelkerken $\mathrm{R}^{2}$ ) muutosta.

\section{Tulokset}

Vastanneiden taustatiedot sukupuolen ja pääasiallisen toiminnan mukaan on esitetty taulukossa 1. Sukupuolten välillä oli eroja siviilisäädyssä ja koulutustasossa siten, että naimattomien ja matalan koulutustason omaavien suhteellinen osuus oli miehillä suurempi kuin naisilla. Myös työkykypistemäärän ja terveydentilan keskiarvo oli miehillä jonkin verran matalampi kuin naisilla. Työttömissä ja eläkeläisissä miesten osuus oli suuri. Työlliset olivat työttömiä ja eläkkeellä olevia nuorempia ja useammin avio- tai avoliitossa. Työllisillä oli myös työttömiä ja eläkeläisiä parempi koulutus. Työkykypistemäärän ja terveydentilan keskiarvo oli työttömillä matalampi kuin työssä olevilla mutta korkeampi kuin eläkeläisillä. Heikentynyt työkyky oli työllisistä 16 prosentilla, työttömistä 37 prosentilla ja eläkkeellä olevista 64 prosentilla. Eri seutukuntien välillä ei ollut vastaajien sukupuolen ja pääasiallisen toiminnan mukaan eroja. (Taulukko 1.) Myöskään koetussa työkyvyssä ei ollut eroja Rovaniemen, Itä-Lapin, Tunturi-Lapin ja PohjoisLapin seutukuntien välillä.

Työkykypistemäärä aleni iän myötä $(\mathrm{p}<.01)$ siten, että se oli 40-44-vuotiailla 8.2, 45-54-vuotiailla 7.9 (miehillä 7.7 ja naisilla 8.0) ja 54-60-vuotiailla 7.5. Työkykypistemäärän ja koetun terveydentilan välinen korrelaatio oli koko aineistossa 0.71 , työssä olevilla korkeampi (0.73) kuin työttömillä tai eläkeläisillä (0.58 ja 0.55).

Lapin seutukunnat eivät tutkimuksen ikäryhmissä eronneet tosistaan sosiaalisiin resursseihin ja psyykkiseen hyvinvointiin liittyvillä muuttujilla. Taulukko 2 kuvaa näitä muuttujia sukupuolen ja pääasiallisen toiminnan mukaan. Sukupuolten välillä oli eroja ainoastaan päihdeongelmassa, jota miehistä raportoi lähes puolet ja naisista viidennes. Työllisten sosiaaliset resurssit ja psyykkinen hyvinvointi olivat kaikilla mittareilla paremmat kuin työttömillä ja eläkeläisillä. Työssä olevilla sosiaalista tukea oli enemmän, elämänhallinta vahvempi ja psyykkisen toimintakyvyn ja hyvinvoinnin ongelmia vähemmän kuin muilla ryhmillä. Työssäkäyvät raportoivat masennusta harvemmin kuin työttömät ja eläkeläiset. Työttömillä todennäköinen päihdeongelma oli yleisempi kuin muissa ryhmissä. Työttömät ja eläkeläiset kokivat mielenterveysongelmien vaarantavan työsuhteen suhteellisesti useammin kuin työssä käyvät.

Taulukon 3 logistisissa regressioanalyyseissa selitetään heikentyneen työkyvyn esiintymistä kaikilla vastaajilla. Mallissa 0 keskitasoinen tai korkea koulutus vähensi heikentyneen työkyvyn todennäköisyyttä ja ilman parisuhdetta eläminen lisäsi sitä. Yhteydet olivat tilastollisesti merkitseviä miehillä, mutta eivät naisilla. Heikentynyt työkyky oli työttömänä, eläkkeellä ja muussa tilanteessa olevilla yleisempää kuin työssä olevilla. Asuinalueella ei ollut tilastollisesti merkitsevää yhteyttä heikentyneeseen työkykyyn.

Vähintään kohtalainen sosiaalinen tuki vähensi heikentyneen työkyvyn todennäköisyyttä, kuten myös vahvempi sosiaalinen 
Taulukko 2. Sosiaalisia resursseja ja psyykkisen hyvinvoinnin ongelmia kuvaavat muuttujat sukupuolen ja pääasiallisen toiminnan mukaan.

\begin{tabular}{|c|c|c|c|c|c|c|c|c|}
\hline & \multicolumn{3}{|l|}{ Sukupuoli } & \multicolumn{4}{|c|}{ Pääasiallinen toiminta } & \multirow[t]{2}{*}{ Kaikki } \\
\hline & Miehet & Naiset & $\mathrm{p}^{1}$ & Työssä & Työtön & Eläkkeellä & $p^{2}$ & \\
\hline $\begin{array}{l}\text { Sosiaalinen tuki } \\
\text { Heikko } \\
\text { Vähintään kohtalainen }\end{array}$ & $\begin{array}{l}34.5 \\
65.5\end{array}$ & $\begin{array}{l}29.6 \\
70.4\end{array}$ & NS & $\begin{array}{l}28.8 \\
71.2\end{array}$ & $\begin{array}{l}44.7 \\
55.3\end{array}$ & $\begin{array}{l}42.2 \\
57.8\end{array}$ & $* * *$ & $\begin{array}{l}32.0 \\
68.0\end{array}$ \\
\hline $\begin{array}{l}\text { Sosiaalinen luottamus } \\
M(s d)\end{array}$ & $6.69(1.83)$ & $6.48(1.95)$ & NS & $6.72(1.83)$ & $6.04(1.88)$ & $6.08(2.45)$ & $* * *$ & $6.59(1.92)$ \\
\hline $\begin{array}{l}\text { Elämänhallinta } \\
M(s d)\end{array}$ & $21.9(4.6)$ & $22.0(4.0)$ & NS & $22.6(3.8)$ & $19.9(4.5)$ & $19.7(5.4)$ & $* * *$ & 21.9 \\
\hline $\begin{array}{l}\text { Psyykkinen roolitoiminta } \\
\text { Ongelmia enintään yksi }\end{array}$ & 79.7 & 80.2 & NS & 84.1 & 63.0 & 69.0 & $* * *$ & 79.9 \\
\hline $\begin{array}{l}\text { Ongelmia useampia } \\
\text { - vähentänyt työhön tai } \\
\text { muuhun toimintaan } \\
\text { käytettyä aikaa, \% }\end{array}$ & $\begin{array}{l}20.3 \\
20.7\end{array}$ & $\begin{array}{l}19.8 \\
16.5\end{array}$ & NS & $\begin{array}{l}15.9 \\
14.1\end{array}$ & $\begin{array}{l}37.0 \\
41.5\end{array}$ & $\begin{array}{l}31.0 \\
29.0\end{array}$ & $* * *$ & $\begin{array}{l}20.1 \\
18.7\end{array}$ \\
\hline $\begin{array}{l}\text { - saanut aikaan vähemmän } \\
\text { kuin olisi halunnut, \% }\end{array}$ & 32.7 & 34.6 & NS & 30.1 & 48.8 & 41.3 & $* * *$ & 33.8 \\
\hline $\begin{array}{l}\text { - ei ole pystynyt } \\
\text { suorittamaan toimintoja } \\
\text { yhtä huolellisesti kuin } \\
\text { tavallisesti, \% }\end{array}$ & 19.4 & 16.9 & NS & 14.3 & 28.0 & 32.7 & $* * *$ & 18.2 \\
\hline $\begin{array}{l}\text { Psyykkistä } \\
\text { rasittuneisuutta, \% }\end{array}$ & 18.1 & 18.2 & NS & 14.0 & 33.7 & 33.3 & $* * *$ & 18.2 \\
\hline Masennus, \% & 10.4 & 14.2 & NS & 10.0 & 20.0 & 19.3 & $* * *$ & 12.3 \\
\hline $\begin{array}{l}\text { Todennäköinen } \\
\text { päihdeongelma, \% }\end{array}$ & 45.7 & 20.4 & $* * *$ & 30.1 & 53.4 & 41.4 & $* * *$ & 33.0 \\
\hline $\begin{array}{l}\text { Työsuhde vaarantuu } \\
\text { mielenterveysongelmien } \\
\text { takia: samaa mieltä, \% }\end{array}$ & 66.2 & 62.0 & NS & 58.5 & 81.0 & 83.8 & *** & \begin{tabular}{|l|}
63.5 \\
\end{tabular} \\
\hline
\end{tabular}

$* \mathrm{p}<.05 ; * * \mathrm{p}<.01 ; * * * \mathrm{p}<.001$

${ }^{1}$ Testeinä Khiin neliö (jakautumat) ja riippumattomien ryhmien t-testi (keskiarvovertailut).

${ }^{2}$ Testeinä Khiin neliö (jakautumat) ja varianssianalyyseissa Brown-Forsythe-testi varianssien erisuuruuden vuoksi.

luottamus ja elämänhallinta. Psyykkiset toiminnanrajoitukset, psyykkinen rasittuneisuus, masennus ja todennäköinen päihdeongelma lisäsivät ja hyvä terveydentila vähensi heikentyneen työkyvyn todennäköisyyttä. Tulokset olivat samanlaiset miehillä ja naisilla lukuun ottamatta päihdeongelmaa, jonka yhteys työkyvyn heikentymiseen näkyi vain miehillä. Myös käsitys työsuhteen vaarantumisesta mielenterveysongelmien takia oli yhteydessä heikentyneeseen työkykyyn kaikilla; yhteys näkyi erityisesti naisilla. (Taulukko 3.)
Mallin 1 mukaan heikentynyt työkyky oli harvinaisempaa niillä, joilla oli vähintään kohtalainen sosiaalinen tuki ja hyvä elämänhallinta, kun taas työttömänä, eläkkeellä ja niin sanotussa muussa tilanteessa oleminen lisäsi heikentyneen työkyvyn todennäköisyyttä. Malliin 2 mukaan otetuista psyykkisen hyvinvoinnin muuttujista psyykkisen roolitoiminnan ongelmat ja masennus lisäsivät heikentyneen työkyvyn todennäköisyyttä. Mallin 3 mukaan työttömänä, eläkkeellä ja muussa tilanteessa oleminen ja psyykkisen roolitoimin- 
Taulukko 3. Taustamuuttujien sekä sosiaalisia resursseja, hyvinvoinnin ongelmia ja terveydentilaa kuvaavien muuttujien yhteydet heikentyneeseen työkykyyn mallin 0 mukaan miehillä ja naisilla sekä koko aineistossa $(n=959)$ '.

\begin{tabular}{|c|c|c|c|c|}
\hline & Miehet & Naiset & Kaikki & \\
\hline & OR & OR & OR & $95 \% \mathrm{Cl}$ \\
\hline Ikä & $1.04^{*}$ & 1.01 & 1.03 & $1.00-1.06$ \\
\hline $\begin{array}{l}\text { Sukupuoli } \\
\text { mies } \\
\text { nainen }\end{array}$ & & & $\begin{array}{l}1 \\
0.78\end{array}$ & $0.58-1.05$ \\
\hline $\begin{array}{l}\text { Parisuhde } \\
\text { avio- tai avoliitossa } \\
\text { naimaton, eronnut tai leski }\end{array}$ & $\begin{array}{l}1 \\
2.77^{* * *}\end{array}$ & $\begin{array}{l}1 \\
1.59\end{array}$ & $\begin{array}{l}1 \\
2.21^{* * *}\end{array}$ & $1.62-3.02$ \\
\hline $\begin{array}{l}\text { Koulutus } \\
\text { matala } \\
\text { vähintään keskitasoinen }\end{array}$ & $\begin{array}{l}1 \\
0.53^{* * *}\end{array}$ & $\begin{array}{l}1 \\
0.56\end{array}$ & $\begin{array}{l}1 \\
0.53 * * *\end{array}$ & $0.38-0.75$ \\
\hline $\begin{array}{l}\text { Pääasiallinen toiminta } \\
\text { työllinen } \\
\text { työtön } \\
\text { eläkkeellä } \\
\text { muu tilanne }\end{array}$ & $\begin{array}{l}1 \\
2.77^{* * *} \\
7.34 * * * \\
15.84^{* *}\end{array}$ & $\begin{array}{l}1 \\
3.85^{* * *} \\
13.84^{* * *} \\
10.56^{* * *}\end{array}$ & $\begin{array}{l}1 \\
3.23 * * * \\
9.53 * * * \\
11.71 * * *\end{array}$ & $\begin{array}{l}1.99-5.23 \\
6.11-14.85 \\
4.88-28.10\end{array}$ \\
\hline $\begin{array}{l}\text { Sosiaalinen tuki } \\
\text { heikko } \\
\text { vähintään kohtalainen }\end{array}$ & $\begin{array}{l}1 \\
0.25^{* * *}\end{array}$ & $\begin{array}{l}1 \\
0.22 * * *\end{array}$ & $\begin{array}{l}1 \\
0.25^{* * *}\end{array}$ & $0.18-0.34$ \\
\hline $\begin{array}{l}\text { Sosiaalinen luottamus } \\
\text { heikko } \\
\text { vahva }\end{array}$ & $\begin{array}{l}1 \\
0.44 * * *\end{array}$ & $\begin{array}{l}1 \\
0.29 * * *\end{array}$ & $\begin{array}{l}1 \\
0.37 * * *\end{array}$ & $0.28-0.51$ \\
\hline $\begin{array}{l}\text { Elämänhallinta } \\
\text { heikko } \\
\text { vahva }\end{array}$ & $\begin{array}{l}1 \\
0.19 * * *\end{array}$ & $\begin{array}{l}1 \\
0.34^{* * *}\end{array}$ & $\begin{array}{l}1 \\
0.25^{* * *}\end{array}$ & $0.18-0.35$ \\
\hline $\begin{array}{l}\text { Työsuhde vaarantuu } \\
\text { mielenterveysongelmien takia } \\
\text { eri mieltä } \\
\text { samaa mieltä }\end{array}$ & $\begin{array}{l}1 \\
1.38\end{array}$ & $\begin{array}{l}1 \\
1.80 *\end{array}$ & $\begin{array}{l}1 \\
1.58^{* *}\end{array}$ & $1.14-2.18$ \\
\hline $\begin{array}{l}\text { Psyykkinen roolitoiminta } \\
\text { ongelmia enintään yksi } \\
\text { useampia }\end{array}$ & $\begin{array}{l}1 \\
9.78 * * *\end{array}$ & $\begin{array}{l}1 \\
4.35^{* * *}\end{array}$ & $\begin{array}{l}1 \\
6.41 * * *\end{array}$ & $4.52-9.10$ \\
\hline $\begin{array}{l}\text { Psyykkistä rasittuneisuutta } \\
\text { ei } \\
\text { kyllä }\end{array}$ & $\begin{array}{l}1 \\
4.95^{* * *}\end{array}$ & $\begin{array}{l}1 \\
7.67^{* * *}\end{array}$ & $\begin{array}{l}1 \\
6.01 * * *\end{array}$ & $4.17-8.65$ \\
\hline $\begin{array}{l}\text { Masennus } \\
\text { ei } \\
\text { kyllä }\end{array}$ & $\begin{array}{l}1 \\
9.36 * * *\end{array}$ & $\begin{array}{l}1 \\
5.76^{* * *}\end{array}$ & $\begin{array}{l}1 \\
6.59 * * *\end{array}$ & $4.37-9.94$ \\
\hline $\begin{array}{l}\text { Todennäköinen päihdeongelma } \\
\text { ei } \\
\text { kyllä }\end{array}$ & $\begin{array}{l}1 \\
2.80 * * *\end{array}$ & $\begin{array}{l}1 \\
1.21\end{array}$ & $\begin{array}{l}1 \\
2.04 * * *\end{array}$ & $1.50-2.80$ \\
\hline Terveydentila & $0.86 * * *$ & $0.88^{* * *}$ & $0.89 * * *$ & $0.87-0.90$ \\
\hline
\end{tabular}

${ }^{1}$ Muuttujien yhteyttä heikentyneeseen työkykyyn tarkasteltiin logistisella regressioanalyysilla, jossa selittäjinä olivat kerrallaan yksi muuttuja ja ikä.

OR = ristitulosuhde, $95 \% \mathrm{Cl}=95 \%$ :n luottamusväli

${ }^{*} p<.05 ; * *<.01 ; * * * p<.001$ 
Taulukko 4. Taustamuuttujien sekä sosiaalisia resursseja, hyvinvoinnin ongelmia ja terveydentilaa kuvaavien muuttujien yhteys heikentyneeseen työkykyyn kolmen mallin mukaan koko aineistossa $(n=959)^{1}$.

\begin{tabular}{|c|c|c|c|c|c|c|}
\hline & \multicolumn{2}{|l|}{ Malli 1} & \multicolumn{2}{|l|}{ Malli 2} & \multicolumn{2}{|l|}{ Malli 3} \\
\hline & OR & $95 \% \mathrm{Cl}$ & OR & $95 \% \mathrm{Cl}$ & OR & $95 \% \mathrm{Cl}$ \\
\hline Ikä & 0.99 & $0.96-1.03$ & 1.00 & $0,96-1,04$ & 1.00 & $0.95-1.05$ \\
\hline $\begin{array}{l}\text { Sukupuoli } \\
\text { mies } \\
\text { nainen }\end{array}$ & $\begin{array}{l}1 \\
0.82 \\
\end{array}$ & $0.56-1.21$ & $\begin{array}{l}1 \\
0.69 \\
\end{array}$ & $0.45-1.06$ & $\begin{array}{l}1 \\
0.87\end{array}$ & $0.53-1.42$ \\
\hline $\begin{array}{l}\text { Parisuhde } \\
\text { avio- tai avoliitossa } \\
\text { naimaton, eronnut tai leski }\end{array}$ & $\begin{array}{l}1 \\
1.18\end{array}$ & $0.78-1.81$ & $\begin{array}{l}1 \\
0.92\end{array}$ & $0.57-1.48$ & $\begin{array}{l}1 \\
0.97\end{array}$ & $0.55-1.68$ \\
\hline $\begin{array}{l}\text { Koulutus } \\
\text { matala } \\
\text { vähintään keskitasoinen }\end{array}$ & $\begin{array}{l}1 \\
1.18\end{array}$ & $0.74-1.90$ & $\begin{array}{l}1 \\
1.23\end{array}$ & $0.73-2.08$ & $\begin{array}{l}1 \\
1.23\end{array}$ & $0.67-2.25$ \\
\hline $\begin{array}{l}\text { Pääasiallinen toiminta } \\
\text { työllinen } \\
\text { työtön } \\
\text { eläkkeellä } \\
\text { muu tilanne }\end{array}$ & $\begin{array}{l}1 \\
2.08^{*} \\
9.24^{* * *} \\
8.40 * * *\end{array}$ & $\begin{array}{l}1.15-3.79 \\
5.26-16.24 \\
2.77-25.44\end{array}$ & $\begin{array}{l}1 \\
1.49 \\
10.39 * * * \\
11.96 * * *\end{array}$ & $\begin{array}{l}0.75-2.94 \\
5.46-19.78 \\
3.68-38.87\end{array}$ & $\begin{array}{l}1 \\
2.27^{*} \\
9.71^{* * *} \\
10.94^{* * *}\end{array}$ & $\begin{array}{l}1.07-4.83 \\
4.60-20.50 \\
2.73-43.76\end{array}$ \\
\hline $\begin{array}{l}\text { Sosiaalinen tuki } \\
\text { heikko } \\
\text { vähintään kohtalainen } \\
\text { Sosiaalinen luottamus } \\
\text { heikko } \\
\text { vahva }\end{array}$ & $\begin{array}{l}1 \\
0.36 * * * \\
1 \\
0.67\end{array}$ & $\begin{array}{l}0.24-0.54 \\
0.24-0.53\end{array}$ & $\begin{array}{l}1 \\
0.38 * * * \\
1 \\
0.77\end{array}$ & $\begin{array}{l}0.24-0.61 \\
0.48-2.60\end{array}$ & $\begin{array}{l}1 \\
0.51^{*} \\
1 \\
0.84\end{array}$ & $\begin{array}{l}0.30-0.88 \\
0.49-1.43\end{array}$ \\
\hline $\begin{array}{l}\text { Elämänhallinta } \\
\text { heikko } \\
\text { vahva }\end{array}$ & $\begin{array}{l}1 \\
0.36^{* * *}\end{array}$ & $0.24-0.53$ & $\begin{array}{l}1 \\
0.56^{*}\end{array}$ & $0.36-0.88$ & $\begin{array}{l}1 \\
0.93\end{array}$ & $0.55-1.57$ \\
\hline $\begin{array}{l}\text { Psyykkinen roolitoiminta } \\
\text { ongelmia enintään yksi } \\
\text { useampia }\end{array}$ & & & $\begin{array}{l}1 \\
2.83^{* * *}\end{array}$ & $1.68-4.76$ & $\begin{array}{l}1 \\
1.95^{*}\end{array}$ & $1.06-3.60$ \\
\hline $\begin{array}{l}\text { Psyykkistä rasittuneisuutta } \\
\text { ei } \\
\text { kyllä }\end{array}$ & & & $\begin{array}{l}1 \\
1.48\end{array}$ & $0.84-2.60$ & $\begin{array}{l}1 \\
0.79\end{array}$ & $0.41-1.53$ \\
\hline $\begin{array}{l}\text { Masennus } \\
\text { ei } \\
\text { kyllä }\end{array}$ & & & $\begin{array}{l}1 \\
2.98 * * *\end{array}$ & $1.64-5.43$ & $\begin{array}{l}1 \\
2.19 *\end{array}$ & $1.11-4.35$ \\
\hline Terveydentila & & & & & $0.89 * * *$ & $0.87-0.92$ \\
\hline Cox \& Snell $R^{2}$ & .211 & & .264 & & .388 & \\
\hline Nagelkerke $\mathrm{R}^{2}$ & .317 & & .399 & & .586 & \\
\hline
\end{tabular}

${ }^{1}$ Muuttujien yhteyttä heikentyneeseen työkykyyn tarkasteltiin logistisilla regressioanalyyseilla, joista mallissa 1 ovat samalla kerralla mukana taustamuuttujat ja sosiaalisia resursseja kuvaavat muuttujat, mallissa 2 niiden lisäksi hyvinvoinnin ongelmia kuvaavat muuttujat ja mallissa 3 edellisten lisäksi koettu terveydentila.

OR = ristitulosuhde, $95 \% \mathrm{Cl}=95 \%$ :n luottamusväli

$* p<.05 ; * * p<.01 ; * * * p<.001$

Todennäköistä päihdeongelmaa ja käsitystä työsuhteen vaarantumisesta mielenterveysongelmien takia koskevat muuttujat eivät sisälly malleihin 1-3. 
nan ongelmat lisäsivät ja parempi terveys ja sosiaalinen tuki vähensivät heikentyneen työkyvyn todennäköisyyttä. (Taulukko 4.)

Vastaavat analyysit tehtiin työssä olevilla. Sosiodemografiset tekijät eivät olleet yhteydessä työkyvyn heikentymiseen. Muilta osin tulokset vastasivat kaikkien vastanneiden tuloksia. Mallissa 1 sosiaalinen tuki ja luottamus sekä elämänhallinta vähensivät työkyvyn heikentymisen todennäköisyyttä. Mallissa 2 tilastollisesti merkitseviä selittäjiä olivat sosiaalinen tuki, elämänhallinta, psyykkisen roolitoiminnan ongelmat, psyykkinen rasittuneisuus ja masennus. Tässä mallissa myös sukupuolen yhteys työkyvyn heikentymiseen oli tilastollisesti merkitsevä. Mallissa 3 vain terveydentilalla oli tilastollisesti merkitsevä yhteys heikentyneeseen työkykyyn.

\section{Pohdinta}

Tutkimuksessa tarkasteltiin koettua työkykyä ja siihen liittyviä sosiaalisia ja hyvinvointia kuvaavia tekijöitä 40-59-vuotiailla Lapissa asuvilla henkilöillä. Koettua työkykyä selvitettiin niin sanotulla työkykypistemäärällä, joka soveltuu paitsi työntekijöiden myös työttömien ja työmarkkinoiden ulkopuolella olevien vastattavaksi (Gould ym. 2015), sillä se ei sido vastauksia senhetkiseen työhön. Koettu työkyky oli yhteydessä vastaajan elämäntilanteeseen sekä useisiin sosiaalisiin ja psyykkisiin resurssitekijöihin.

Vastanneiden koettu työkyky oli matalampi kuin saman ikäisen väestön työkyky Suomessa Terveys 2011 -tutkimuksessa, jonka mukaan 45-54-vuotiaan väestön työkykypistemäärän keskiarvo oli miehillä 8.4 ja naisilla 8.5 (Gould ym. 2012b). Vastausprosentti oli kuitenkin matala, ja huono terveys, työttömyys ja huono-osaisuus ovat tutkimusten mukaan yleisempiä vastaamatta jättäneillä kuin vastanneilla (ks. Lindén-Boström \&t Persson 2012). Siten on todennäköistä, että tutkimus arvioi 40-59-vuotiaan väestön työkyvyn todellista myönteisemmäksi eli ero Terveys 2011 -tutkimuksen tuloksiin saattaa olla edellä todettua suurempi. Naisten koettu työkyky oli hieman parempi kuin miesten, mikä näkyy myös työmarkkina-asemassa siten, että miesten osuus sekä työttömissä että eläkeläisissä oli selvästi naisten osuutta suurempi. Sosiaalisissa resursseissa ja psyykkisen hyvinvoinnin ongelmissa, esimerkiksi masennuksessa, miehet ja naiset eivät kuitenkaan eronneet toisistaan. Päihdeongelmaan viittaavaa päihteiden käyttöä esiintyi tutkittavilla paljon, miehistä lähes puolella vastaajista.

Tarkasteltaessa elämäntilanteen ja työkyvyn yhteyksiä huomio kiinnittyy erityisesti työttömien ryhmään. Työttömät sijoittuvat sekä työkyvyn että terveydentilan arviossaan työssä olevien ja eläkeläisten väliin, mutta muilta osin työttömät ovat lähempänä eläkkeellä kuin työssä olevia. Koulutustason mataluus ja ilman parisuhdetta olevien suuri osuus on tyypillistä sekä työttömille että eläkeläisille. Ryhmät raportoivat myös sosiaalisen tuen puutetta, sosiaalisen pääoman niukkuutta ja psyykkisen hyvinvoinnin vajeita keskenään samaan tapaan ja työssä käyvistä poiketen. Päihteidenkäyttö on yleistä ja ongelmallista sekä työttömillä että eläkeläisillä, työttömillä kuitenkin yleisempää kuin eläkeläisillä. Kyse on toisaalta tyypillisistä sosiaalisen ja työmarkkinoilta syrjäytymisen riskitekijöistä, toisaalta siitä, että työn puute voi johtaa sosiaalisten verkostojen hapertumiseen ja edelleen henkisen hyvinvoinnin heikentymiseen (esim. Gallie ym. 2003).

Perustutkinnon jälkeisen ammatillisen koulutuksen puute tai vähäisyys oli tämän tutkimuksen mukaan yhteydessä heikentyneeseen työkykyyn koko aineistossa, mutta naisilla ja työssä käyvillä yhteydet eivät olleet tilastollisesti merkitseviä. Matala koulutus näyttäytyy riskitekijänä työttömäksi joutumisen ja eläkkeelle siirtymisen kannalta; sen sijaan sopivan työn saaneilla koulutuksen puute ei välttämättä toimi työkykyisyyden riskitekijänä. Talala ym. (2014) katsovat, että työttömyys ja siihen liittyvät toimeentulo-ongelmat voivat toimia matalan koulutustason ja työkyvyn alenemisen yhteyttä välittävinä tekijöinä.

Merkille pantavaa on toisaalta, että tutkimuksen eläkeläisistä - jotka käytännössä olivat pysyvällä työkyvyttömyyseläkkeellä tai kuntoutustuella - kolmannes piti työkykyään 
kyselyhetkellä hyvänä. Arviot viittaavat siihen, että eläkkeellä olevien joukossa on potentiaalia tehdä kokopäiväistä tai ainakin osapäiväistä tai tilapäistä työtä. Gouldin ja Kalivan (2010) eläkeläisten työssäkäyntihalukkuutta koskevat luvut ovat paljon matalampia. Tämän tutkimuksen eläkeläisillä ja työttömillä työelämästä syrjäytymisen syyt eivät liene pelkästään henkilökohtaisen työkyvyn heikentymisessä, vaan suurelta osin ulkoisissa olosuhteissa, kykyjen ja tarjoutuvien mahdollisuuksien välisessä epäsuhdassa. Lapin työttömyysaste on kuulunut Kainuun ja PohjoisKarjalan ohella maan korkeimpiin. Erityisesti pitkäaikaistyöttömyys on ollut yleistä, ja siihen liittyy yleisesti korkea ikä (Lapin ELYkeskus 2013). Pitkäaikaistyöttömien joukossa on runsaasti työkyvyttömyyttä ja tyydyttämätöntä hoidon ja kuntoutuksen tarvetta, jota ei ole tunnistettu peruspalvelujen piirissä (Kerätär 2015). Työmahdollisuuksien vähetessä terveydellisten ongelmien merkitys mahdollisuuksien sulkijoina korostuu, kun taas hyvä työllisyystilanne ja monipuolinen elinkeinorakenne helpottavat myös heikentyneen työkyvyn omaavien ja osatyökyvyttömyyseläkkeellä olevien mahdollisuuksia jatkaa työssä. Pitkäaikaistyöttömien ja pitkällä sairauslomalla olevien koettu työkunto on yhteydessä myös ammatillisiin valmiuksiin, ympäristön tarjoamiin mahdollisuuksiin ja haluun jatkaa työntekoa (Järvikoski ym. 1999, Berglind \&t Gerner 2002).

Koetun terveydentilan yhteys koettuun työkykyyn oli tässä tutkimuksessa voimakas, kuten aikaisemmin Terveys 2000 -tutkimuksen aineistossa (Koskinen ym. 2006). Erityisen voimakas se oli työssä käyvillä, jopa niin voimakas, että kokonaismallissa terveydentila jäi ainoaksi tilastollisesti merkitseväksi selittäjäksi. Laajan kansainvälisen tutkimuksen mukaan koetun työkyvyn ja terveyden väliset korrelaatiot työntekijöillä ovat selvästi alhaisempia (McGonagle ym. 2014). Voidaankin kysyä Koskista ym:ita (2006) mukaillen, perustavatko suomalaiset työntekijät työkykyarvionsa pitkälle suomalaisen sosiaalivakuutusjärjestelmän sairaus- tai vammaperus- teisiin kriteereihin.

Mielenterveyden ongelmien, erityisesti masennuksen, yhteys työkykyyn on todettu erilaisissa väestöaineistoissa (esim. Koskinen ym. 2006). Myös Lapin väestössä psyykkisen hyvinvoinnin ongelmilla oli voimakas yhteys heikentyneeseen työkykyyn. Erityisesti psyykkisellä roolitoiminnalla ja masennuksella oli koetun työkyvyn kannalta itsenäinen merkitys, joka säilyi koko aineistossa myös silloin, kun koettu terveydentila on mukana. Psyykkisen hyvinvoinnin vajeet muodostavat ihmisten työkykykokemuksissa oman alueensa, jonka sisältö ei ole luokiteltavissa pelkästään yleisen terveydentilakäsitteen alle. Psyykkinen roolitoiminta edusti tässä tutkimuksessa työssä tai päivittäisessä toiminnassa realisoituvaa psyykkistä toimintakykyä: se kuvasi erilaisissa tehtävissä suoriutumista, aikaansaamista ja toiminnan tulosta.

Elämänhallinnan tunne kehittyy sekä varhaisempien elämänkokemusten että viimeaikaisen elämäntilanteen pohjalta, keskeisinä elämänpiireinä perhe, työ ja talous (Bandura 1999). Tässä tutkimuksessa elämänhallinnan tunne oli sekä työttömillä että eläkeläisillä heikompi kuin työssä olevilla, mikä viittaa konkreettisten elämäntapahtumien merkitykseen (vrt. Lachman \& Weaver 1998). Hallinnan tunne on kuitenkin yhteydessä työkykyyn paitsi koko väestössä myös työssä käyvillä. Hallinnan tunne vaikuttaa niihin valintoihin, joita ihminen elämässään tekee, ja on mahdollista, että vahvan hallinnan tunteen omaavat niin työntekijät kuin työelämästä syrjäytyneetkin etsivät keskimääräistä aktiivisemmin tapoja kehittää ja ylläpitää työkykyään (vrt. McGonagle ym. 2015, Brouwer ym. 2010).

Myös sosiaalisia resursseja kuvaavat muuttujat olivat tässä tutkimuksessa yhteydessä heikentyneeseen työkykyyn. Ilman parisuhdetta eläminen oli yhteydessä heikentyneeseen työkykyyn koko aineistossa, mutta erityisesti miehillä. Ilman parisuhdetta olevien miesten suurempi työkyvyn alenemisen tai työkyvyttömyyseläkkeelle joutumisen riski on raportoitu myös muissa tutkimuksissa (Pensola \&t Järvikoski 2006b, Rantala 2008). 
Parisuhteessa elämisen itsenäinen merkitys katosi kuitenkin, kun malliin lisättiin sosiaalinen tuki. Parisuhde on erityisesti miehillä tärkeä sosiaalisen tuen lähde, mutta tukea on mahdollista saada myös muualta. Tässä tutkimuksessa sosiaalinen tuki suojasi heikentyneen työkyvyn kokemukselta sekä miehiä että naisia koko aineistossa ja työssä olevilla. Sen itsenäinen merkitys säilyi myös kokonaismallissa, jossa kaikki muuttujat terveydentilaa myöten olivat mukana. Sosiaalinen tuki ja verkostot voivat ongelmien kohdatessa auttaa työkyvyn ylläpitämisessä, vahvistaa luottamusta ratkaisujen löytymiseen ja myös avata mahdollisuuksia työelämässä jatkamiseen ja uuteen työhön. Lapissa muun muassa pitkät etäisyydet ja työperäinen muuttoliike voivat johtaa verkostojen hajoamiseen ja luontaisen tuen heikentymiseen.

Sosiaalista tukea koskevat tutkimustulokset ovat keskenään ristiriitaisia, sillä tuen merkitys voi vaihdella muun muassa vastaanottajan tilanteen ja saatavilla olevan tai annetun tuen laadun mukaan (Brouwer ym. 2010, Karlsson ym. 2010). Sosiaalisen tuen ja luottamuksen kääntöpuolta heijastaa mielenterveysongelmiin liittyvä stigma. Lähes kaksi kolmannesta kaikista vastanneista ja yli neljä viidesosaa työttömistä ja eläkeläisistä arveli työntekijän työsuhteen olevan vaarassa, jos hänen mielenterveysongelmansa tulee ilmi. Kielteisten asenteiden kokeminen oli myös yhteydessä koettuun työkykyyn. Vastaavalla tavalla Solem (2008) on raportoinut ikään liittyvien kielteisten stereotypioiden ja itsensä leimaamisen heijastuvan työkykyyn.

Tutkimuksen rajoituksena on postikyselyn matala vastausprosentti, jollaista on kuitenkin pidetty hyväksyttävänä vastaavanlaisissa, anonymiteettiin perustuvissa survey-tutkimuksissa (Bethge ym. 2012, Koolhaas ym. 2012). Vastaajaryhmittäistä vaihtelua kompensoitiin painokertoimien avulla. Painokertoimien avulla ei kuitenkaan voida poistaa sitä, että huono terveys, työttömyys ja huonoosaisuus ovat yleensä yleisempiä vastaamatta jättäneiden kuin vastanneiden keskuudessa, toisin sanoen tutkimuksen tulokset antavat todennäköisesti liian positiivisen kuvan La- pin väestön työkyvystä (vrt. Lindén-Boström Ct Persson 2012). Ongelman muodostaa luonnollisesti myös se, että koettua työkykyä tutkitaan ilman työtä ja työhistoriaa koskevia tietoja. Koska kyseessä on poikkileikkaustutkimus, syy-seuraussuhteita koskevia johtopäätöksiä tuloksista ei ole mahdollista tehdä.

Menetelmällisistä ongelmista huolimatta tutkimus kiinnittää huomion työttömien ja työelämän ulkopuolella olevien henkilöiden hyvinvointivajeisiin. Se osoittaa myös, että työllisen työvoiman ulkopuolella, työttöminä ja työkyvyttöminä, on Lapissakin huomattava joukko ihmisiä, joiden työkyky heidän oman arvionsa mukaan riittäisi työntekoon. Terveystekijöiden ja elämäntilanteen ohella hallinnan tunteella ja sosiaalisella tuella on oleellinen merkitys työkyvyn heikentymisessä ja työelämän ongelmissa. Tämä merkitsee, että työkykyä ylläpitävää toimintaa ja työhön palaamista tukevaa kuntoutusta suunniteltaessa tulisi huomio kohdistaa myös hallinnan tunnetta vahvistaviin ja sosiaalista tukea tuottaviin tilanteisiin ja verkostoihin. Huono työllisyystilanne ja elinkeinorakenteen yksipuolisuus vaikeuttavat Lapissa työkykynsä heikentyneeksi kokevien mahdollisuuksia jatkaa työssä tai palata työmarkkinoille. Syrjäytymisen ja eläköitymisen ehkäisyn näkökulmasta on tarpeen hyväksyä erilaisuus osaksi työelämää ja pyrkiä luomaan lisää työllistymismahdollisuuksia myös niille, joiden työkyky on tavalla tai toisella heikentynyt. Ammatillisen kuntoutuksen kehittämisessä tulisi näihin näkökohtiin kiinnittää enemmän huomiota.

\section{Tiivistelmä}

Heikentyneeseen työkykyyn yhteydessä olevien tekijöiden selvittäminen on tärkeää pyrittäessä ehkäisemään työelämästä syrjäytymistä ja parantamaan kuntoutuksen suuntaamista. Työkyvyn muutokset ovat 40 vuotta täyttäneillä yleisempiä kuin nuoremmissa ikäryhmissä. Tutkimuksen tavoitteena oli selvittää sosiaalisten resurssien ja psyykkiseen hyvinvointiin liittyvien tekijöiden yhteyttä 
työkyvyn heikentymiseen Lapissa asuvilla 40-59-vuotiailla henkilöillä. Tiedonkeruu toteutettiin Lapin sairaanhoitopiirissä syksyllä 2012. Postikyselyn otos oli 8200 henkilöä ja vastausprosentti 33 . Ikäryhmään 40-59 vuotta kuului vastanneista 959 (vastausprosentti 32). Heikentynyt työkyky määriteltiin työkykypistemäärän avulla (arvo 0-7 asteikolla 0-10). Analyysimenetelmänä oli logistinen regressioanalyysi. Terveys ja työkyky olivat työssä olevilla paremmat ja eläkeläisillä heikommat kuin työttömillä. Psyykkisen hyvinvoinnin ongelmia oli työttömillä ja eläkeläisillä yhtä paljon. Pääasiallinen toiminta, sosiaalinen tuki, psyykkinen roolitoiminta, depressio ja terveydentila olivat tilastollisesti merkitsevästi yhteydessä heikentyneeseen työkykyyn kokonaismallissa, joka sisälsi myös sosiodemografiset taustamuuttujat. Tietoja työkykyä selittävistä tekijöistä voidaan käyttää hyväksi pohdittaessa työkykyä ylläpitävän toiminnan ja kuntoutuksen mahdollisuuksia.

\section{Abstract}

Perceived work ability and related factors with middle-aged people living in Lapland Perceived work ability predicts continuing at work or withdrawal to disability pension. The aim of the study was to investigate the associations of social, psychological and health factors with work ability in persons aged 40-59 years, living in Lapland. The total sample of the study was 8200 persons and the response rate 33. The number of persons aged 40-59 was 959 (response rate 32). A single-item work ability measure (work ability compared with the life time best) was used. With the unemployed, health and work ability were weaker than with those at work and better than with those at pension. Logistic regression analysis was used in determining the associations of social, psychological and health factors with work abili- ty. In the total model, life situation, social support, psychological role functioning, depression and state of health were statistically significant predictors among all respondents, whereas health was the most important predictor among those at work. Information of factors associated with work ability is needed when developing strategies for rehabilitation and maintaining work ability.

Aila Järvikoski, YTT, professori (emerita), kuntoutustiede, Lapin yliopisto

Kristiina Härkäpää, FT, professori, kuntoutustiede, Lapin yliopisto

Marjo Romakkaniemi, YTT, yliopistonlehtori, sosiaalityö, Lapin yliopisto

Esa Nordling, PsT, kehittämispäällikkö, Mielenterveysyksikkö, Terveyden ja hyvinvoinnin laitos

\section{Lähteet}

Aalto A-M, Aro A, Teperi J (1999) RAND-36 terveyteen liittyvän elämänlaadun mittarina. Mittarin luotettavuus ja suomalaiset väestöarvot. Tutkimuksia 101. Stakes, Helsinki.

Aalto A-M, Elovainio M, Kivimäki M, Uutela A, Pirkola S (2012) The Beck depression inventory and General Health Questionnaire as measures of depression in the general population: a validation study using the Composite International Diagnostic Interview as the gold standard. Psychiatry Res 197,163-171.

Ahlstrom L, Grimby-Ekman A, Hagberg M, Dellve L (2010) The work ability index and single-item question: associations with sick leave, symptoms, and health - a prospective study of women on long-term sick leave. Scand J Work Environ Health 36, 404-12.

Ahola K, Joensuu M, Mattila-Holappa P, Tuisku K, Vahtera J, Virtanen M (2014) Mielenterveyssyistä työkyvyttömien nuorten aikuisten tausta. Suomen Lääkärilehti 69, 50-52.

Alavinia SM, de Boer AGEM, van Duivenbooden JC, Frings-Dresen MHW, Burdorf A (2009) Determinants of work ability and its predictive value for disability. Occup Med 59, 32-37.

Bandura A (1999) Self-efficacy. The exercise of control. Freeman, New York. 
Berglind H, Gerner U (2002) Motivation and return to work among the long-term sicklisted: an action theory perspective. Disabil Rehabil 24, 719-726.

Bethge M, Radoschewski FM, Gutenbrunner C (2012) The work ability index as a screening tool to identify the need for rehabilitation: Longitudinal findings from the second German sociomedical panel of employees. J Rehab Med 44, 980-987.

Brevik JI, Dalgard 0 (1996) The Health Profile Inventory. Oslo.

Brooks R, EuroQol Group (1996) EuroQol: the current state of play. Health Policy 37, 53-72.

Brouwer S, Reneman MF, Bultmann U, van der Klink JJL, Groothof JW (2010) A prospective study of return to work across health conditions: perceived work attitude, self-efficacy and perceived social support. J Occup Rehabil 20, 104-112.

Dhalla S, Kopec JA (2007) The CAGE Questionnaire for alcohol misuse: A review of reliability and validity studies. Clin Invest Med 30, 33-41.

Ewing JA (1968) Detecting alcoholism: The Cage Questionnaire. JAMA 252, 1905-7.

Forsman A, Herberts K, Aromaa E, Tuulari J, Wahlbeck K (2009) Kohti pohjalaista hyvinvointia: Mielenterveyttä koskeva kyselytutkimus 2008. Menetelmäraportti. Avauksia 3/2009. Terveyden ja hyvinvoinnin laitos, Helsinki.

Gallie D, Paugam S, Jacobs S (2003) Unemployment, poverty and social isolation: Is there a vicious circle of social exclusion? European Societies 5, 1, 1-32.

Giordano GN, Lindström M (2016) Trust and health: testing the reverse causality hypothesis. J Epidemiol Community Health 70, 10-16.

Goldberg DP (1972) The detection of psychiatric illness by questionnaire. Oxford University Press, London.

Gould R, Härkäpää K, Järvikoski A (2012a) Mitä kuntoutuksen jälkeen? Teoksessa Gould R, Härkäpää K, Järvikoski A (toim.) Toimiiko työeläkekuntoutus? Eläketurvakeskuksen tutkimuksia 01/2012. Eläketurvakeskus, Helsinki, 193-228.

Gould R, Koskinen S, Sainio P, Blomgren J, Kivekäs J, Ilmarinen J, Husman P, Seitsamo J (2012b) Työkyky. Teoksessa: Koskinen S, Lundqvist A, Ristiluoma N (toim.) Terveys, toimintakyky ja hyvinvointi Suomessa 2011. Raportti 68/2012, Terveyden ja hyvinvoinnin laitos, 141-144.

Gould R, Härkäpää K, Koskinen S (2015) Työkyvyn arviointi väestötutkimuksissa. Toimia-verkosto. (http://www.thl.fi/toimia/tietokanta/media/files/suositus/2015/11/30/ Tyokyvyn_arviointi_vaestotutkimuksissa_VALMIS2.pdf.)

Gould R, Ilmarinen J, Järvisalo J, Koskinen S (toim.) (2006a) Työkyvyn ulottuvuudet. Terveys 2000 -tutkimuksen tuloksia. ETK, Kela, KTL, TTL, Helsinki.

Gould R, Kaliva K (2010) Työkyvyttömyyseläke ja ansiotyö. Eläketurvakeskuksen raportteja 5. Eläketurvakeskus, Helsinki.

Gould R, Koskinen S, Seitsamo J, Tuomi K, Polvinen A, Sainio P (2006b) Aineisto ja menetelmät. Teoksessa Gould R, Ilmarinen J, Järvisalo J, Koskinen S (toim.) Työkyvyn ulottuvuudet. ETK, Kela, KTL, TTL, Helsinki, 35-54.

Härkäpää K (1992) Psychosocial factors as predictors for early retirement in patients with chronic low back pain. J Psychosom Res 36,553-559.

Ilmarinen J, Gould R, Järvikoski A, Järvisalo J (2006) Työkyvyn moninaisuus. Teoksessa Gould R, Ilmarinen J, Järvisalo J, Koskinen S (toim.) Työkyvyn ulottuvuudet. ETK, Kela, KTL, TTL, Helsinki, 1734.

Järvikoski A, Peltoniemi J, Puumalainen J (1999) Ikääntyneet pitkäaikaistyöttömät terveydenhuollossa ja kuntoutuspalveluissa. Tutkimuksia 61. Kuntoutussäätiö, Helsinki.

Karlsson N, Skargren E, Kristenson M (2010) Emotional support predicts more sickness absence and poorer self-assessed work ability: a two-year prospective cohort study. BMC Public Health 10, 648-58.

Kerätär R (2015) Kun katsoo kauempaa, näkee enemmän. Monialainen työkyvyn ja kuntoutustarpeen arviointi pitkäaikaistyöttömillä. Acta Universitatis Ouluensis D Medica 1340. Oulun yliopisto, Oulu.

Kessler RC, Andrews G, Mroczek D, Ustün TB, Wittchen H-U (1998) The World Health Organization Composite International Diagnostic Interview ShortForm (CIDI-SF). Int J Methods Psychiatr Res 7, 171-185.

Koolhaas W, van der Klink JJL, Groothoff JW, Brouwer S (2012) Towards a sustainable healthy working life: associations between chronological age, functional age and work outcomes. Eur J Public Health 22, 424-429.

Koskinen S, Martelin T, Sainio P, Gould R (2006) Työkyky ja terveys. Teoksessa Gould R, Ilmarinen J, Järvisalo J, Koskinen S (toim.) Työkyvyn ulottuvuudet. ETK, Kela, KTL, TTL, Helsinki, 114-134.

Laaksonen M, Gould R (2013) Regional differences in disability retirement: explaining between-county differences in Finland. Scand J Work Environ Health 39, 609-17.

Lachman ME, Weaver SL (1998) The sense of control as a moderator of social class differences in health and well-being. J Person Soc Psychol 74, 763-73.

Lapin ELY-keskus (2013) Lapin työllisyyskatsaus syyskuu. Elinkeino-, liikenne- ja ympäristökeskus, 
Lapin ELY-keskus.

Lederer V, Loisel P, Rivard M, Champagne F (2014) Exploring the diversity of conceptualizations of work (dis)ability: A scoping review of published definitions. J Occup Rehabil 24, 242-267.

Lindén-Boström M, Persson C (2012) A selective follow-up study on a public health survey. European Journal of Public Health 23, 152-157.

Martelin T, Sainio P, Koskinen S, Gould R (2006) Työkyky eri asuinalueilla ja kieliryhmissä. Teoksessa Gould R, Ilmarinen J, Järvisalo J, Koskinen S (toim.) Työkyvyn ulottuvuudet. Terveys 2000 -tutkimuksen tuloksia. ETK, Kela, KTL, TTL, Helsinki, 64-70.

McGonagle AK, Barnes-Farrell JL, Fisher GG, Grosch JW (2015) Individual and work factors related to perceived work ability and labor force outcomes. J Appl Psychol 100, 376-398.

McGonagle AK, Barnes-Farrell JL, Milia LD, Fischer FM, Hobbs BBB, Iskra-Golec I, Kaliterna L, Smith L (2014) Demands, resources, and work ability: A cross-national examination of health care workers. Eur J Work Org Psychol 23, 830-846.

Millet P, Sandberg KW (2003) Locus of control and its relationship with vocational rehabilitation outcomes of unemployed sick leaves in Sweden. J Vocat Rehabil 19, 59-66.

Nyman H, Kiviniemi M (2015) Katsaus eläketurvaan vuonna 2014. Tilastoraportteja 04/2015. Eläketurvakeskus, Helsinki.

Nyqvist F, Forsman AK, Cattan M (2013) A comparison of older workers' and retired older people's social capital and sense of mastery. Scand J Public Health 41, 792-798.

Pasternack I, Autti-Rämö I, Hinkka K, Pappila J (2015) Miten tunnistaa varhaiskuntoutuksen tarve työelämässä? Kirjallisuuskatsaus työkyvyn heikkenemisen ennusmerkeistä ja varhaisen tunnistamisen työkaluista. Sosiaali- ja terveysturvan selosteita 91. Kela, Helsinki.

Pearlin LI, Nguyen KB, Schieman S, Milkie MA (2007) The life-course origins of mastery among older people. J Health Soc Behav 48,164-179

Pearlin LI, Schooler C (1978) The structure of coping. J Health Soc Behav 19, 1, 2-21.

Pensola T, Gould R, Polvinen A (2010) Ammatit ja työkyvyttömyyseläkkeet. Masennukseen, muihin mielenterveyden häiriöihin sekä tuki- ja liikuntaelinten sairauksiin perustuvat eläkkeet. Sosiaalija terveysministeriön selvityksiä 2010:16. Sosiaali- ja terveysministeriö, Helsinki.

Pensola T, Järvikoski A (2006a) Sosiaalinen tuki ja osallistuminen. Teoksessa Gould R, Ilmarinen J,
Järvisalo J, Koskinen S (toim.) Työkyvyn ulottuvuudet. ETK, Kela, KTL, TTL, Helsinki, 190-196.

Pensola T, Järvikoski A (2006b) Työkyky siviilisääty- ja perherakenneryhmissä. Teoksessa Gould R, Ilmarinen J, Järvisalo J, Koskinen S (toim.) Työkyvyn ulottuvuudet. ETK, Kela, KTL, TTL, Helsinki, 97-103.

Rahkonen 0, Laaksonen M, Lallukka T, Lahelma E (2011) Sosiaaliluokkien välisten terveyserojen selittäminen ja niiden vähentämisen haaste. Esimerkkinä työkyvyttömyyseläkkeelle joutuminen. Janus 19, 358-368.

Rantala J (2008) Varhainen eläkkeelle siirtyminen. Eläketurvakeskuksen tutkimuksia 2008:1. Eläketurvakeskus, Helsinki.

Rinaldi M, Perkins R, Glynn E, Montibeller T, Clenaghan M, Rutherford J (2008) Individual placement and support: From research to practice. Advances in Psychiatric Treatment 13, 50-60.

Solem PE (2008) Age changes in subjective work ability. International Journal of Ageing and Later Life $3,2,43-70$.

Stephens T, Dulberg C, Joubert N (2000) Mental health of the Canadian population: A comprehensive analysis. Chronic Dis Can 20, 118-126.

Suikkanen A, Viinamäki L, Selkälä A (2014) Hyvinvointibarometrien ja -selontekojen tuloksia hyvinvointipoliittisesta näkökulmasta. Teoksessa: Viinamäki L (toim.) Tunturi-Lapin seutukunnan hyvinvointibarometri 2013. Sarja A: Tutkimukset 4/2013. Lapin ammattikorkeakoulu, Kemi, 308317.

Talala K, Härkänen T, Martelin T ym. (2014) Koulutusryhmien väliset terveys- ja hyvinvointierot edelleen suuria. Suomen Lääkärilehti 69, 2185-2192.

Thoits PA (2011) Mechanisms linking social ties and support to physical and mental health. J Health Soc Behav 52, 145-161.

Tuomi K, Ilmarinen J, Jahkola M, Katajarinne L, Tulkki A (1997a) Työkykyindeksi. Työterveyshuolto 19. Työterveyslaitos, Helsinki.

Tuomi K, Ilmarinen J, Seitsamo J, Huuhtanen P, Martikainen R, Nygård CH, Klockars M (1997b) Summary of the Finnish research project (1981-1992) to promote the health and work ability of aging workers. Scand J Work Environ Health 23, 66-71.

Viinamäki L (2014) (toim.) Tunturi-Lapin seutukunnan hyvinvointibarometri 2013. Sarja A: Tutkimukset 4/2013. Lapin ammattikorkeakoulu, Kemi. 